\title{
Research Summary of Historical Geography in China in Recent Ten Years
}

\author{
Xing Zheng
}

College of History and Culture of Northwest Normal University, Lanzhou Gansu, 730070, China

Keywords: Historical geography of China, Big data, Valuation.

\begin{abstract}
It is to do statistic analysis to total 799 articles in Journal of Chinese Historical Geography recorded by SCNI Database from 2005 to 2014 by quantitative analysis, summarize the characteristic and development tendency of historical geography study in our country in recent ten years and point out the current situation and deficiency of domestic historical geography domain so as to provide references to academic research and disciplinary development.
\end{abstract}

\section{Year Distribution and Fund Subsidizing Condition of Papers}

Counting the quantity of papers published in Journal of Chinese Historical Geography in the recent years could contribute to understand the development tendency and study venation of this journal. By searching in CNKI, it could clearly count there are total 799 articles in Journal of Chinese Historical Geography in the recent years whose general year distribution is as following. On the whole, the quantity of papers published in Journal of Chinese Historical Geography in the recent years kept smooth and steady from 2005. Though there were some fluctuations by chance, except quantity of papers in 2005 more than that in the other years, the whole quantity of paper had no wide decrease. It showed that quantity of paper published in Journal of Chinese Historical Geography in the recent years maintained developing with a steady pace.

By quantitative statistics to each fund program, it could have a rough idea of the funding and emphasis of nation and each department to historical geography study. Among the 799 articles in Journal of Chinese Historical Geography in the recent years, 176 of them have been funded by nation and each department, occupying nearly $22.03 \%$. The year distribution condition of articles with fund could be seen in the form 1 below.

Table 1. Funding Condition of Published Articles in Journal of Chinese Historical Geography in Recent Ten Years

\begin{tabular}{|c|c|c|c|c|c|c|c|c|}
\hline$d$ Fun & $\begin{array}{l}\text { Nationa } \\
\text { l social } \\
\text { sciences }\end{array}$ & $\begin{array}{l}\text { Nationa } \\
\text { l nature }\end{array}$ & $\begin{array}{l}\text { Nation } \\
\text { and } \\
\text { others }\end{array}$ & $\begin{array}{l}\text { Ministry } \\
\text { of } \\
\text { Educatio } \\
n\end{array}$ & $\begin{array}{l}\text { Other } \\
\text { ministries } \\
\text { and } \\
\text { commissions }\end{array}$ & $\begin{array}{l}\text { Province } \\
\text { and city }\end{array}$ & $\begin{array}{l}\text { Other } \\
\text { funds } \\
\text { Total }\end{array}$ & Total \\
\hline 2005 & 3 & 5 & 1 & 2 & 1 & 1 & 1 & 14 \\
\hline 2006 & 2 & 2 & 2 & & & 1 & 1 & 8 \\
\hline 2007 & 6 & 5 & 2 & & 1 & 1 & 1 & 16 \\
\hline 2008 & 2 & 9 & 1 & 1 & 1 & 1 & & 15 \\
\hline 2009 & 7 & 2 & 1 & 2 & 1 & 1 & & 14 \\
\hline 2010 & 7 & 4 & 2 & 2 & & & 1 & 16 \\
\hline 2011 & 9 & 5 & 2 & 1 & 1 & 1 & 1 & 20 \\
\hline 2012 & 10 & 5 & 1 & 3 & 1 & 1 & & 20 \\
\hline 2013 & 18 & 4 & 1 & & 1 & & 1 & 25 \\
\hline 2014 & 14 & 8 & 3 & 1 & 1 & & & 27 \\
\hline
\end{tabular}




\begin{tabular}{|l|l|l|l|l|l|l|l|l|}
\hline Total & 78 & 49 & 16 & 12 & 8 & 7 & 6 & 176 \\
\hline
\end{tabular}

In addition, according to the data in Form 1, it shows that the historical geography study in our country didn't get deserved attention at early phase, with few funding articles. Such condition has some connection with few article samples and project beginning. After 2011, funding articles became more and more, especially in the recent three years. From the funding types, the sustentation funds for our historical geography study are mainly National Philosophy and Social Science Fund, Natural Science Foundation of China, other funds of national level as well as funds from Ministry of Education. And funds from province and city are comparatively less. It shows that our historical geography study has gained great development with national funds in recent ten years.

\section{Citation Frequency Condition of Papers}

The top ten data of citation frequency of papers published in Journal of Chinese Historical Geography from CNKI is as Form 2. The citation frequency of an individual paper is at most 37 times. There are 5 papers with more than 30 times of citation frequency. And those papers with top ten citation frequency were published from 2005 to 2008. From the research contents of these papers, they mainly referred to historical settlement geography, historical economic geography, historical medical science, historical administrative division geography, historical physical geography, etc. Among these papers, Northern Settlement Transition in Shanxi in Ming Dynasty of Wang Jieyu has the most citation frequency.

In addition, other paper with high citation frequency such as Economic Pattern Transition Study in Shandong in Modern Times --- from the View of Port and Interior Interaction from Chen Weizhong was with the view of coastal port and interior interaction in Shandong in 1860s, demonstrated the difference between interior and ports as well as the areal division of labor in interior which caused unbalance of regional economic development in Shandong. It thought such unbalance had big influence to the current regional economic development in Shandong. According to various literatures and data, Research of Regularity of Pestilence Spatial and Temporal Distribution in the Period of Wei, Jin and Southern and Northern Dynasties by Gong Shengsheng, Ye Huping counted the geographical distribution condition of geographical distribution in the Period of Wei, Jin and Southern and Northern Dynasties, with the middle and lower reaches of the Yellow River region, Huai River basin, the middle and lower reaches of Changjiang River as the main pestilence regions.

Table 2. Top Ten Citation Frequency of Papers in Journal of Chinese Historical Geography in Recent Ten Years

\begin{tabular}{|c|c|c|c|}
\hline Paper Title & $\begin{array}{c}\text { Published } \\
\text { Time }\end{array}$ & Author & $\begin{array}{c}\text { Citation } \\
\text { Times }\end{array}$ \\
\hline $\begin{array}{c}\text { Northern Settlement Transition in Shanxi in } \\
\text { Ming Dynasty }\end{array}$ & 2006 & Wang Jieyu & 37 \\
\hline $\begin{array}{c}\text { Economic Pattern Transition Study in } \\
\text { Shandong in Modern Times --- from the } \\
\text { View of Port and Interior Interaction }\end{array}$ & 2005 & $\begin{array}{c}\text { Chen } \\
\text { Weizhong }\end{array}$ & 32 \\
\hline $\begin{array}{c}\text { Research of Regularity of Pestilence } \\
\text { Spatial and Temporal Distribution in the } \\
\text { Period of Wei, Jin and Southern and } \\
\text { Northern Dynasties }\end{array}$ & 2007 & $\begin{array}{c}\text { Ye Huping } \\
\text { Sheng }\end{array}$ & 31 \\
\hline $\begin{array}{c}\text { Transition of Territory Control by Emperor } \\
\text { Wu in the Western Han Dynasty }\end{array}$ & 2008 & Xin Deyong & 30 \\
\hline $\begin{array}{c}\text { Historical Research and Enlightenment of } \\
\text { Urban Planning and Development Relation } \\
\text { in Qingdao in Modern Times }\end{array}$ & 2007 & Li Dongquan & 29 \\
\hline \begin{tabular}{c} 
Discovery and Environmental \\
\hline
\end{tabular} & 2006 & Wang Naiang, & 32 \\
\hline
\end{tabular}




\begin{tabular}{|c|c|c|c|}
\hline $\begin{array}{c}\text { Significance of Old Townsite of the "Liuhu } \\
\text { Zhou" State }\end{array}$ & $\begin{array}{c}\text { He Tonghui, } \\
\text { etc. }\end{array}$ & \\
\hline $\begin{array}{c}\text { Polders Development in Ancient South of } \\
\text { Yangtze River and its Influence to } \\
\text { Ecological Environment }\end{array}$ & 2005 & $\begin{array}{c}\text { Zhuang } \\
\text { Huafeng }\end{array}$ & 28 \\
\hline $\begin{array}{c}\text { Provincial Process of Regions South of the } \\
\text { Yangtze River, Hubei and Hunan Provinces } \\
\text { and Shaanxi Province and Transition of } \\
\text { Provincial System in the Early Qing Dynasty }\end{array}$ & 2008 & Fu Linxiang & 25 \\
\hline $\begin{array}{c}\text { Shanxi Hsing Tu-ssu and its Garrison } \\
\text { Establishment in Ming Dynasty }\end{array}$ & 2008 & Ma Shunping & 24 \\
\hline $\begin{array}{c}\text { Fuel Replacement History and Forest } \\
\text { Distribution Transition --- with the Upper } \\
\text { Reaches of Yangtze River in Recent 2000 } \\
\text { Years as Time-and-space Background }\end{array}$ & 2007 & $\begin{array}{c}\text { Lan Yong, } \\
\text { Haung } \\
\text { Quansheng }\end{array}$ & 23 \\
\hline
\end{tabular}

\section{Frequency of High-yield Authors}

Among the authors with papers in Journal of Chinese Historical Geography in the recent ten years, there are total 10 authors with top published papers, five of them with more than 5 published articles. They are from different scientific research institutions which publish most articles. Man Zhimin published 11 articles, Wu Hongqi 9 articles. Combining Form 2 and Form 3, it finds that though Man Zhimin published most articles, the citation times are not many. Though Xin Deyong only published 6 articles, one has been cited for many times. In addition, by analysis, we could find that Man Zhimin, Wu Hongqi, Yang Yuda, Guo Shengbo and Xin Deyong are the five representatives of domestic historical geography study in recent ten years.

Table 3. High-yield Authors ith Published Articles in Journal of Chinese Historical Geography in Recent Ten Years

\begin{tabular}{|c|c|c|}
\hline Author & $\begin{array}{c}\text { Quantity of } \\
\text { articles }\end{array}$ & Institutions \\
\hline Man Zhimin & 11 & Historical Geography Research Center of Fudan University \\
\hline $\begin{array}{c}\text { Wu } \\
\text { Hongqi }\end{array}$ & 9 & $\begin{array}{c}\text { Historical Geography Research Center of Ji'nan } \\
\text { University }\end{array}$ \\
\hline Yang Yuda & 7 & Historical Geography Research Center of Fudan University \\
\hline Guo Shengbo & 7 & Historical Geography Research Center of Ji'nan University \\
\hline Xin Deyong & 6 & $\begin{array}{c}\text { Ancient Chinese History Research Center of Peking } \\
\text { University }\end{array}$ \\
\hline Pan Sheng & 5 & $\begin{array}{c}\text { Historical Geography Institution in School of City and } \\
\text { Environment in Peking University }\end{array}$ \\
\hline Hou Yongjian & 5 & $\begin{array}{c}\text { Northwest Institute of Environment and Development in } \\
\text { Shanxi Normal University }\end{array}$ \\
\hline Shi Hongshuai & 5 & $\begin{array}{c}\text { Northwest Institute of Environment and Development in } \\
\text { Shaanxi Normal University }\end{array}$ \\
\hline Han Guanghui & 5 & School of City and Environment in Peking University \\
\hline Zhou Hongwei & 5 & $\begin{array}{c}\text { Northwest Institute of Environment and Development in } \\
\text { Shanxi Normal University }\end{array}$ \\
\hline
\end{tabular}

\section{Analysis of Institutions with Published Papers}

Institutions with published papers mean the units author signed when publishing the articles. Statistic analysis to the institutions with published papers could help to clearly understand their geographical distribution and regional attentions. This article uses SATI to extract institutions from EndNote files of papers in Journal of Chinese Historical Geography in the recent ten years and then carry out frequency statistics, counting 24 academic institutions of top 13 frequency of occurrence and dispatching quantity more than or equal to 7 , as Table 4. 
Table 4.

\begin{tabular}{|c|c|c|c|c|c|c|c|}
\hline Institution & $\begin{array}{l}\text { Quantit } \\
\mathrm{y}\end{array}$ & Site & $\begin{array}{l}\text { Rankin } \\
\text { g }\end{array}$ & Institution & $\begin{array}{l}\text { Quantit } \\
\mathrm{y}\end{array}$ & Site & $\begin{array}{l}\text { Rankin } \\
\text { g }\end{array}$ \\
\hline $\begin{array}{l}\text { Fudan } \\
\text { University }\end{array}$ & 129 & Shanghai & 1 & $\begin{array}{l}\text { Shanxi } \\
\text { University }\end{array}$ & 11 & $\begin{array}{l}\text { Taiyuan in } \\
\text { Shanxi }\end{array}$ & 10 \\
\hline $\begin{array}{l}\text { Shaanxi } \\
\text { Normal } \\
\text { University }\end{array}$ & 119 & Xi'an & 2 & $\begin{array}{l}\text { Zhejiang } \\
\text { University }\end{array}$ & 9 & Hangzhou & 11 \\
\hline $\begin{array}{l}\text { Peking } \\
\text { University }\end{array}$ & 53 & Beijing & 3 & CCNU & 8 & Wuhan & 12 \\
\hline $\begin{array}{l}\text { Ji'nan } \\
\text { University }\end{array}$ & 33 & Guangzhou & 4 & $\mathrm{CNU}$ & 8 & Beijing & 12 \\
\hline $\begin{array}{l}\text { Southwest } \\
\text { University }\end{array}$ & 22 & Chongqing & 5 & $\begin{array}{l}\text { Shanghai } \\
\text { Normal } \\
\text { University }\end{array}$ & 8 & Shanghai & 12 \\
\hline $\begin{array}{l}\text { Wuhan } \\
\text { University }\end{array}$ & 15 & Wuhan & 6 & $\mathrm{XMU}$ & 8 & Xiamen & 12 \\
\hline $\begin{array}{l}\text { Northwest } \\
\text { University }\end{array}$ & 14 & Xi'an & 7 & SCU & 7 & Chengtu & 13 \\
\hline RUC & 13 & Beijing & 8 & $\begin{array}{l}\text { Henan } \\
\text { University }\end{array}$ & 7 & Kaifeng & 13 \\
\hline NJU & 13 & Nanjing & 8 & $\begin{array}{l}\text { Hunan Normal } \\
\text { University }\end{array}$ & 7 & Changsha & 13 \\
\hline SJTU & 12 & Shanghai & 9 & $\begin{array}{l}\text { Northwest } \\
\text { Normal } \\
\text { University }\end{array}$ & 7 & Lanzhou & 13 \\
\hline Yunnan & 12 & $\begin{array}{l}\text { University } \\
\text { Kunming }\end{array}$ & 9 & NKU & 7 & Tianjin & 13 \\
\hline $\mathrm{BNU}$ & 11 & Beijing & 10 & $\begin{array}{l}\text { Chinese } \\
\text { Academy of } \\
\text { Social Sciences } \\
\text { in Beijing }\end{array}$ & 7 & Beijing & 13 \\
\hline
\end{tabular}

According to the statistic data in Form 4, Fudan University and Shaanxi Normal University totally published 248 articles, occupying 31\% of the total articles in Journal of Chinese Historical Geography in the recent ten years, which shows that these two universities are our key positions for historical geography study. Fudan University possesses the first focused research bases of humanistic and social science by Ministry of Education --- Historical Geography Research Center. And Shaanxi Normal University possesses one of the 100 research bases of humanistic and social science by Ministry of Education --- Northwest Research Institute of Historical Environment and Economic Social Development. This is the important reason for these two universities to gain numerous historical geography achievements and become the study key position.

\section{Conclusion}

By quantitative analysis, it is to do big data analysis to 799 articles in Journal of Chinese Historical Geography recorded by CNKI in the recent ten years from such aspects as publishing time, funding condition, frequency of author occurrence, citation frequency of papers, dispatching institution distribution, etc. reflecting two main characteristics of historical geography study in China in recent ten years.

Firstly, quantity of papers published in Journal of Chinese Historical Geography in the recent ten years keeps smooth and steady development. Though there are some fluctuations, the overall quantity of paper has no bid decrease. As for the funding condition, funding is obviously increased, with the biggest proportion and higher funding level of National Social Science Funds and National Science Foundation, less of local funds. It shows that steady development of our historical geography study is inseparable with national attention to this discipline and constant funding. 
Secondly, it forms a rather stable author group in historical geography study in the recent ten years. According to the frequency of author occurrence in Journal of Chinese Historical Geography in the recent ten years, it could see that five representative high-yield authors such as Man Zhimin, Wu Hongqi, Yang Yuda, Guo Shengbo and Xin Deyong make contributions to the historical geography study. As to the scientific research institutions where authors are, Beijing, Shanghai, Guangzhou, $\mathrm{Xi}$ 'an, Wuhan, etc. are the rather congregate regions for academic institutions of historical geography study. Fudan University and Shaanxi Normal University are the weighted key positions for historical geography study.

\section{Acknowledgments}

Task name of this article: Folk Local Culture in Northwest Region and the Modern Significance Study. Task No.: 13YJCZH104.

\section{References}

[1] Lihe, Yuan Cuimin, Li Yafeng, Big Data Research Overview Based on Bibliometrics. Information Science, 2014, 06:148-155.

[2] Zhong Saixiang, Qu Bo, Su Xiangyan, Mao Peng, You Xibing, Characteristic and Tendency of Chinese Geography from Journal of Geographical Sciences --- Based on Bibliometrics. Journal of Geographical Sciences, 2014, 08:1077-1092.

[3] Li Fan, Situ Shangji, Document Analysis of Cultural Geography in China in Recent Twenty Years. Human Geography, 2007, 01:105-111.

[4] Fan Liwen, Sun Liangji, Chen Jidong, Biliometric Analysis to Journal of Beijing Sport University in 2006. Information Science, 2008, 02:240-246.

[5] Xu Yifang, Xu Xin, Hou Shijun, Biliometric Analysis of Our Commercial Group: Based on Data in CNKI (2005-2012). Journal in Southwest University for Nationalities (humanistic and social science), 2013, 05:225-231. 